\title{
Figure, Tables, and Maps
}

Figure I Selected Members of the Rodriguez Family, Sandy Bay 65

Table I Prices of Commodities Sold in Tasbapauni, 1969-75 I23

Table 2 Labor Hierarchy by Ethnic Group in the Camilo Ortega Sugar Mill, Kukra Hill, $1983 \quad$ I30

Table 3 Internalized Racism and Community Leadership in $\begin{array}{ll}\text { Sandy Bay } & \text { I } 58\end{array}$

Table 4 Miskitu Ethnic Militancy and the Autonomy Law

$\begin{array}{ll}\text { Compared } & 192\end{array}$

Map I Central America xviii

Map 2 Atlantic Coast of Nicaragua 3

Map 3 Río Grande Zone 5

Photographs appear on pp. 95 and 177 and following pp. 46 and ${ }_{1} 62$ 
